\title{
Technical Evaluation of Two 6-kW Mono-Si Photovoltaic Systems at the National Renewable Energy Laboratory
}

E.E. van Dyk, T. Strand, and R. Hansen Presented at the 25th IEEE Photovoltaic Specialists Conference, May 13-17, 1996, Washington, D.C.

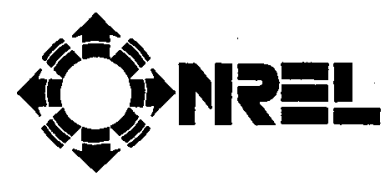

National Renewable Energy Laboratory 1617 Cole Boulevard

Golden, Colorado 80401-3393

A national laboratory of the U.S. Department of Energy Managed by Midwest Research Institute for the U.S. Department of Energy under contract No. DE-AC36-83CH10093

Prepared under Task No. PV610101

May 1996 


\section{NOTICE}

This report was prepared as an account of work sponsored by an agency of the United States government. Neither the United States government nor any agency thereof, nor any of their employees, makes any warranty, express or implied, or assumes any legal liability or responsibility for the accuracy, completeness, or usefulness of any information, apparatus, product, or process disclosed, or represents that its use would not infringe privately owned rights. Reference herein to any specific commercial product, process, or service by trade name, trademark, manufacturer, or otherwise does not necessarily constitute or imply its endorsement, recommendation, or favoring by the United States govemment or any agency thereof. The views and opinions of authors expressed herein do not necessarily state or reflect those of the United States government or any agency thereof.

Available to DOE and DOE contractors from:

Office of Scientific and Technical Information (OSTI)

P.O. Box 62

Oak Ridge, TN 37831

Prices available by calling (423) 576-8401

Available to the public from:

National Technical Information Service (NTIS)

U.S. Department of Commerce

5285 Port Royal Road

Springfield, VA 22161

(703) $487-4650$ 


\title{
TECHNICAL EVALUATION OF TWO 6-kW MONO-Si PHOTOVOLTAIC SYSTEMS AT THE NATIONAL RENEWABLE ENERGY LABORATORY
}

\author{
E. Ernest van Dyk, Troy Strand, and Robert Hansen \\ National Renewable Energy Laboratory, 1617 Cole Boulevard, Golden, CO 80401, USA \\ * On leave from the Department of Physics, University of Port Elizabeth, PO Box 1600, \\ Port Elizabeth, 6000, South Africa.
}

\begin{abstract}
This paper presents an analysis of performance data on the two 6-kW ac grid-connected photovoltaic systems at the National Renewable Energy Laboratory (NREL). The performance parameters analyzed include de and ac power, aperture efficiency, energy, capacity factor and performance index which are compared to plane-of-array irradiance, ambient temperature, and back-of-module temperature as a function of time, either daily or monthly. Power ratings of the systems were also obtained for data corresponding to different test conditions. This study has shown, in addition to expected seasonal trends, that system monitoring is a valuable tool in assessing performance and detecting faulty equipment. In addition, methods applied for this study may be used to evaluate and compare systems employing different cell technologies.
\end{abstract}

\section{INTRODUCTION}

The goal of this study was to evaluate and compare the performance of two identical $6-\mathrm{kW}_{\mathrm{ac}}$ grid-connected photovoltaic (PV) systems located on the roof of the Solar Energy Research Facility (SERF) building at NREL in Golden, Colorado. The systems began operation on March 23, 1994. The evaluation was done by the analysis of performance data obtained by continuous system monitoring for the period August 1, 1994, to July 31, 1995. The performance parameters analyzed include dc and ac power, aperture area efficiency, energy, capacity factor, and performance index. These parameters are compared to plane-of-array (POA) irradiance, ambient temperature, and back-of-module temperature as a function of time, either daily or monthly. The energy output of the systems was also simulated using PVFORM, a simulation program. The power ratings of the systems were also obtained for data corresponding to different test conditions. Finally, system losses were determined.

The results show, in addition to expected seasonal trends, that system monitoring is a valuable tool in assessing performance and detecting faulty equipment. Each system was given an estimated rating of $6 \mathrm{~kW}_{\mathrm{ac}}$ based on Photovoltaics for Utility-Scale Applications (PVUSA) test conditions (PTC). ${ }^{\dagger}$ The systems were found to produce a similar amount of total energy, but were operating at approximately $7 \%$ below their estimated rating. This may be attributed to the design inverter efficiency being estimated at $95 \%$ (compared with the measured value of $88 \%$ ) and the module aperture-area efficiency being estimated at $12.8 \%$ (compared with the measured value of $11.0 \%$ ). The continuous monitoring also revealed faulty software in the peak-power-point tracking equipment. Furthermore, the methods applied in this study may be used to evaluate and compare systems employing different cell technologies.

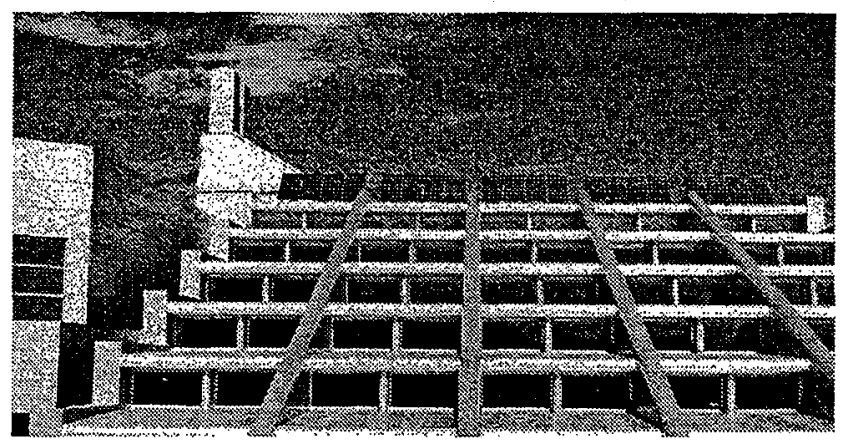

Fig. 1. Photograph showing the SERFEAST array.

\section{SYSTEM DESCRIPTION}

Each system, comprising a monocrystalline Si array, was estimated at $6 \mathrm{~kW}_{\mathrm{ac}}$ under PTC when deployed. The SERF arrays each consist of 140 PV modules connected with the following configuration: 5 source circuits, each with one positive and one negative monopole; each monopole consists of 14 series-connected modules. The

$\dagger \quad$ PTC: PVUSA test conditions - $1000 \mathrm{~W} / \mathrm{m}^{2}$ POA irradiance, $20^{\circ} \mathrm{C}$ ambient temperature, and $1 \mathrm{~m} / \mathrm{s}$ wind speed. 
dc rating of each array at standard test conditions (STC) ${ }^{\ddagger}$ is $7.43 \mathrm{~kW}$. This dc rating was obtained by summation of module peak power at STC. The arrays are mounted on the roof of the SERF building at a fixed tilt of $45^{\circ}$ from the horizontal and aligned with the building, approximately $15^{\circ}$ east of true south. The SERF building is located at $39.7^{\circ} \mathrm{N}$ latitude and $105^{\circ} \mathrm{W}$ longitude and the elevation is approximately $1800 \mathrm{~m}$ [1]. The systems are identified as SERFEAST and SERFWEST, corresponding to their position on the SERF building. The SERFEAST array is shown in Figure 1.

\section{DATA ACQUISITION}

The data acquisition is centered around Campbell Scientific data loggers connected to a computer via modem link, with data sampled every $5 \mathrm{~s}$ and stored as $15 \mathrm{~min}$ averages. The data are estimated to be accurate to $\pm 1 \%$. For the purposes of this study, the performance data were restricted to those collected between August 1 , 1994, and July 31, 1995.

\section{RESULTS AND DISCUSSION}

Figure 2 shows the dc and ac power (normalized to $1000 \mathrm{~W} / \mathrm{m}^{2}$ ), back-of-module temperature, aperture efficiency, and inverter efficiency as a function of time over the period monitored for the SERFWEST system. The data were restricted to POA irradiance greater than $850 \mathrm{~W} / \mathrm{m}^{2}$ for analysis of power and associated parameters. The heavy solid lines represent a 50-point moving average for each parameter and are included to serve merely as a guide to the eye. From the figure, the expected inverse correlation between system output and back-of-module temperature is clearly demonstrated.

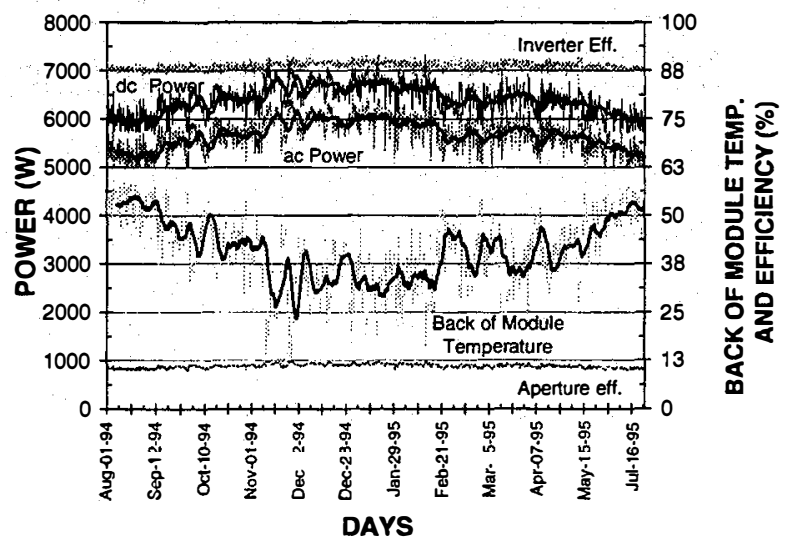

Fig. 2. Normalized dc and ac power, back-of-module temperature, aperture-area efficiency, and inverter efficiency vs. time for the SERFWEST system.

The aperture-area efficiency is defined as the ratio $P_{\text {out }} / P_{\text {in }}$, where $P_{\text {in }}$ is the POA irradiance for net module

‡ STC: Standard test conditions $-1000 \mathrm{~W} / \mathrm{m}^{2}$ POA irradiance, $25^{\circ} \mathrm{C}$ cell temperature, and air mass 1.5 global spectrum. aperture area (module area excluding frame) of system and $P_{\text {out }}$ is the dc power output. The annual average aperture area efficiency was determined to be $11.0 \%$, compared with the design value of $12.8 \%$. This discrepancy may be attributed, in part, to various array losses that were not adequately accounted for and to prevailing weather conditions. It should be noted that the annual average aperture efficiency based on all the data collected was determined to be $10.5 \%$.

The system losses, which ultimately determine system performance, may result from array losses and those associated with dc to ac conversion. The array losses are caused by wiring, module shadowing, soiling, degradation, reflection, and effects related to temperature and spectral variations. The energy lost because of array losses, excluding temperature, was determined to be $10.6 \%$ as measured relative to the STC array rating. The temperature losses were found to be as high as $13 \%$ when modules operate at $55^{\circ} \mathrm{C}$. The losses associated with dc to ac power conversion on power conditioning equipment used are easily quantified by direct measurement of dc- and ac-power outputs. These losses are illustrated in Figure 2 by the inverter efficiency, defined as the ratio $P_{a d} / P_{d c}$. The annual average inverter efficiencies determined using POA irradiances above $850 \mathrm{~W} / \mathrm{m}^{2}$ were $88.6 \%$ and $88.3 \%$ for the SERFWEST and SERFEAST systems, respectively. This is approximately $7 \%$ below the design inverter efficiency of $95 \%$. At $75 \%$ of full load $\left(6 \mathrm{~kW}_{\mathrm{ac}}\right)$, the inverter should run at $95 \%$. It should, however, be noted that the annual inverter efficiencies based on all data collected were $86.7 \%$ and $86.4 \%$ for the SERFWEST and SERFEAST systems, respectively. The cumulative effect of all the system losses is about $30 \%$ of possible energy generation as determined by the array STC ratings of $7.43 \mathrm{~kW}$ per system.

The total annual dc energy produced by the two systems was 12.0 MWh and 11.8 MWh for SERFEAST and SERFWEST, respectively. The monthly energy produced shows variation caused by seasonal insolation and prevailing weather conditions. These variations, spring and fall maxima and corresponding winter and summer minima, are depicted in Figure 3 , together with energy production as predicted by a modeling program, PVFORM [2]. PVFORM uses actual radiation and meteorological data to simulate output based on system parameters and typical system losses. The radiation and meteorological data used are direct radiation, global horizontal radiation, ambient temperature and wind speed. These data were obtained from the Reference Meteorology and Irradiance Station (RMIS) at NREL [3,4]. The RMIS irradiance data is accurate to $\pm 3 \%$ for global horizontal, $\pm 1 \%$ for direct normal, and $\pm 5 \%$ modeled irradiance $[4,5]$. The total dc energy as obtained by the simulation differs from the actual SERFWEST energy produced by $1.5 \%$, thereby indicating the significance of performing a simulation. It must, however, be stressed that by performing a simulation many input parameters influence the ultimate output and may therefore be misleading. During the months in which a significant difference between measured and simulated energy is observed, the 
difference may be attributed to either temperature effects or snow on the arrays. More specifically, the lower measured energy in September, June, and July could be attributed to temperature and weather patterns, while the March difference may be ascribed to snow on the arrays. It is worth noting that the unusually low energy production of the SERFEAST system in July 1995 may be accounted for by the fact that the peak-power tracking equipment had a software error. This error resulted in the low energy production and does, in part, account for the difference in total energy production. The error was corrected in August 1995.

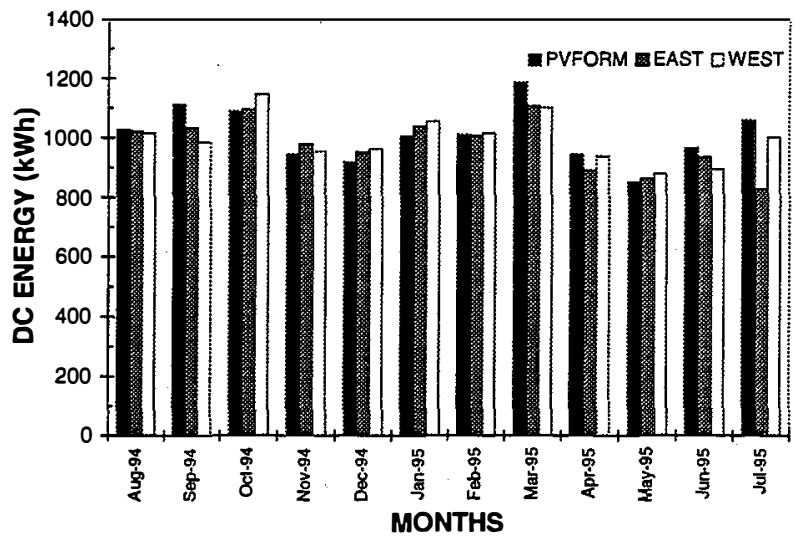

Fig. 3. Comparison of actual dc energy with simulated dc energy for both systems. The simulation was performed using PVFORM and employing RMIS data.

Seasonal trends in performance are also depicted in Figure 4 by the monthly capacity factors and performance indices, calculated using the estimated PTC system rating of $6 \mathrm{~kW}_{\mathrm{ac}}$ and shown as percentages. The low SERFEAST system performance in July may be accounted for by the faulty peak-power tracker as discussed above. The capacity factors for May are the lowest, excluding July SERFEAST data. This may be attributed to adverse weather conditions. The performance index, however, shows that May is a good month. This is because the reduced irradiance in May is accounted for in determining the performance index; this may be misleading as it could be assumed that May is a high energy producing month, which is not the case. The performance index does, however, show that in May the systems performed well under the prevailing conditions.

Outdoor power ratings were obtained for the systems relative to STC, PTC, and Nominal Operating Cell Temperature (NOCT) $)^{\S}$ under the conditions of the Nominal Terrestrial Environment (NTE). For these calculations the data were restricted as follows:

STC: POA irradiances $>750 \mathrm{~W} / \mathrm{m}^{2}$ and back-ofmodule temperature between $23^{\circ} \mathrm{C}$ and $27^{\circ} \mathrm{C}$,

$\S$ NOCT: Nominal Operating Cell Temperature - cell temperature at NTE - $800 \mathrm{~W} / \mathrm{m}^{2}$ POA irradiance, $20^{\circ} \mathrm{C}$ air temperature, and $1 \mathrm{~m} / \mathrm{s}$ wind speed.
PTC: POA irradiances $>750 \mathrm{~W} / \mathrm{m}^{2}$ and ambient temperature between $18^{\circ} \mathrm{C}$ and $22^{\circ} \mathrm{C}$ and $1 \mathrm{~m} / \mathrm{s}$ wind speed, and

NOCT: POA irradiances between $750 \mathrm{~W} / \mathrm{m}^{2}$ and $850 \mathrm{~W} / \mathrm{m}^{2}$, ambient temperature between $18^{\circ} \mathrm{C}$ and $22^{\circ} \mathrm{C}$ and wind speed between $0.8 \mathrm{~m} / \mathrm{s}$ and $1.2 \mathrm{~m} / \mathrm{s}$.

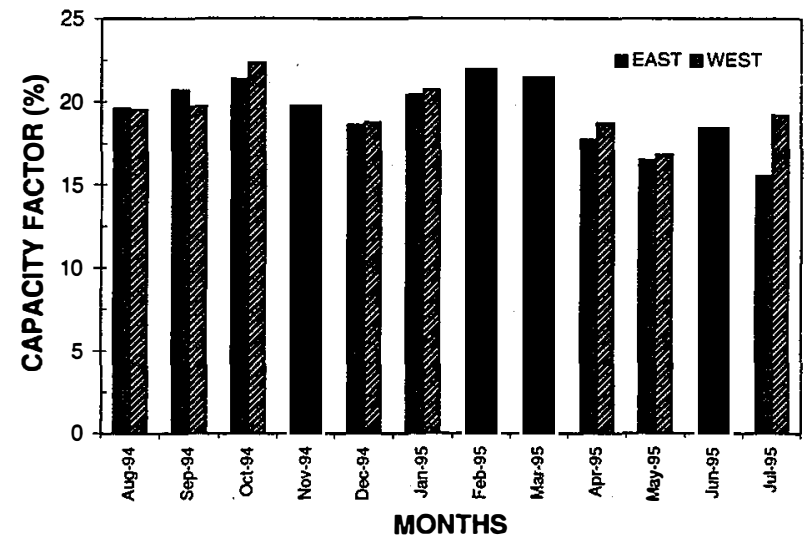

Fig. 4 (a). Monthly capacity factor for both SERFEAST and SERFWEST systems.

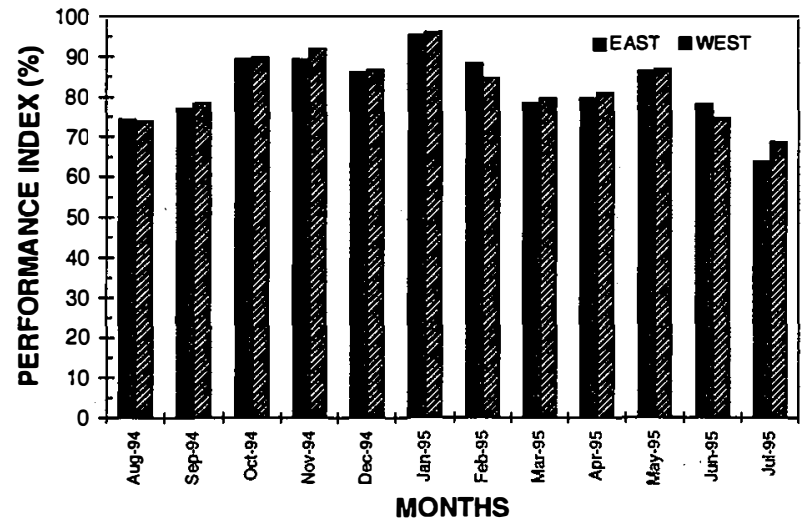

Fig. 4 (b). Monthly performance index for both SERFEAST and SERFWEST systems.

The dc and ac power, as a function of POA irradiance for the SERFEAST system, is shown in Figure 5 for PTC. The solid lines represent a least-squares fit to each data set, with the appropriate equation also shown. The outdoor ratings at the above-mentioned test conditions are summarized in Table 1 below.

Table 1. Outdoor rating of systems at different test conditions. The NOCT values are normalized to $1000 \mathrm{~W} / \mathrm{m}^{2}$ for comparison.

\begin{tabular}{|c|c|c|c|c|}
\hline \multirow{2}{*}{$\begin{array}{c}\text { Ref. } \\
\text { Condition }\end{array}$} & \multicolumn{2}{|c|}{ DC POWER (W) } & \multicolumn{2}{c|}{ AC POWER (W) } \\
\cline { 2 - 5 } & East & West & East & West \\
\hline STC & 6851 & 6857 & 6140 & 6157 \\
\hline PTC & 6260 & 6287 & 5509 & 5563 \\
\hline NOCT & 6408 & 6463 & 5720 & 5814 \\
\hline
\end{tabular}




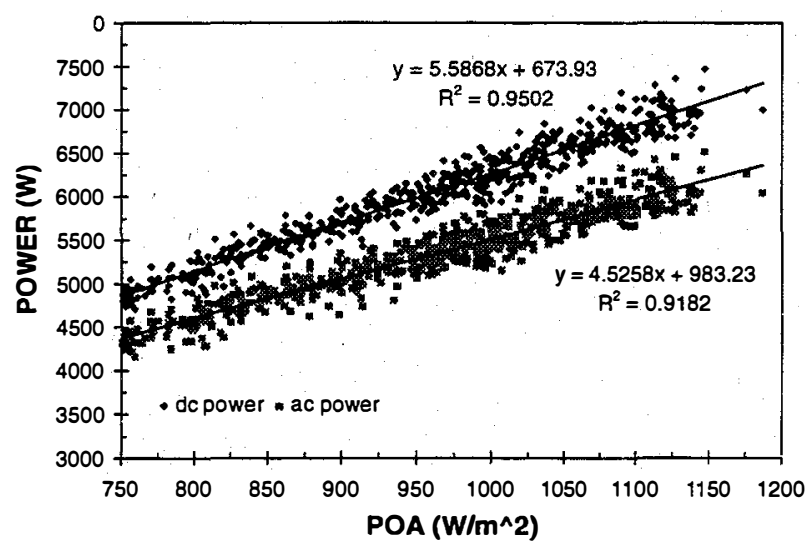

Fig. 5. SERFEAST dc and ac power as function of POA irradiance for PTC outdoor rating.

From Table 1, it is evident that the systems do not perform as predicted. The PTC estimate of the systems is $6 \mathrm{~kW}_{\mathrm{ac}}$, and the measured outdoor rating is lower than this by $7.3 \%$ and $8.2 \%$ for the SERFEAST and SERFWEST systems, respectively. This lower outdoor rating may be attributed, in part, to the fact that the inverters operate at lower annualized efficiencies of about $88 \%$ compared to the rated $95 \%$.

\section{SUMMARY AND CONCLUSIONS}

The data obtained from continuous system monitoring used to evaluate and compare performance of the two systems showed that the systems operated in a similar manner. The expected seasonal fluctuations for monocrystalline $\mathrm{Si}$ were also observed. These seasonal variations (spring and fall maxima and corresponding winter and summer minima) are clearly illustrated by analyzing energy production data and associated parameters. The analysis of energy produced also illustrated the value of continuous monitoring to detect faulty equipment, as was the case for the peak-power tracking software. Furthermore, the energy produced was also modeled using a simulation program. This simulation, using system design parameters, yielded a total dc energy that is comparable with that measured, thereby illustrating the value of modeling system energy output. When modeling system performance, the application of system derating was found to be critical.

The analysis of system power output showed that the systems were overrated (at PTC) by approximately $7 \%$ to $8 \%$. This may be attributed to the design inverter efficiency being estimated at $95 \%$, compared with the measured value of approximately $87 \%$, as well as the aperture-area efficiency being overestimated. The average measured aperture-area efficiency was $11.0 \%$, which is significantly lower than the design value of $12.8 \%$.
The annual average capacity factor and performance index were determined to be $19.6 \%$ and $82.5 \%$, respectively. The performance index was, however, found to be misleading for the months with adverse weather conditions, as was the case for May 1995.

An analysis of the system losses revealed that, when excluding the effect of temperature, the average array losses amounted to $10.6 \%$ of potential energy production as measured relative to STC array rating. The temperature losses may be as high as $13 \%$ when modules operate at elevated temperatures. The annual average of dc to ac conversion losses was found to be about $13 \%$ of the generated dc power. The cumulative effect of all the system losses is about $30 \%$ of the dc array rating at STC.

Finally, the methods of analysis, as applied in this study, may be used to evaluate different systems comprising different cell technologies.

\section{ACKNOWLEDGMENTS}

The authors wish to thank Roland Hulstrom and Dick DeBlasio for their support. The assistance of Daryl Myers in supplying RMIS data and for many useful discussions is acknowledged. Ben Kroposki is acknowledged for supplying temperature coefficient data and useful discussions.

This work was supported by NREL under Contract No. DOE-AC36-83CH10093 to the U.S. Department of Energy.

The work was also conducted as part of a joint project between NREL and the University of Port Elizabeth, South Africa.

[1] T. Strand, L. Mrig, and R. Hansen, "Technical Evaluation of Photovoltaic Systems at NREL," PV Performance and Reliability Workshop, Lakewood, CO, September 1994

[2] D.F. Menicucci, J.P. Fernandez, "User's Manual for PVFORM: A Photovoltaic System Simulation Program for Stand-Alone and Grid-Interactive Applications," SAND850376, April 1991.

[3] D.R. Myers, private communication.

[4] D.R. Myers and T.W. Cannon, "Photovoltaic Solar Radiometric Measurements and Evaluation," 13th NREL Photovoltaics Program Review, Lakewood, CO. AIP Conference Proceedings 353, America Institute of Physics, Woodbury, NY.

[5] D.R. Myers, "Uncertainty Analysis for Thermopile Pyranometer and Pyrheliometer Calibrations Performed by SERI," SERI TR/215-3294. Solar Research Institute, Golden, CO, April 1988. 